\title{
CHARTA ZÁKLADNÝCH PRÁV EÚ A PREKONANIE SAMO OBMEDZUJÚCEHO PRÍSTUPU ÚSTAVNÉHO SÚDU SR V KONANIACH O SÚLADE PRÁVNYCH PREDPISOV
}

\author{
MARTINA JÁNOŠÍKOVÁ
}

\begin{abstract}
The Charter of Fundamental Rights of the EU and the overcoming of the self-limiting approach of the Constitutional Court of the Slovak Republic in proceedings dealing with the compatibility of the legislation

Is it possible to speak of the existence of a doctrine of the Constitutional Court of the Slovak Republic in relation to the Charter of the Fundamental Rights of the European Union? This is the key question dealt with in the following article. The answer stems from two decisions of the Constitutional Court delivered within proceedings dealing with the compatibility of legislation. The Constitutional Court initially took a self-limiting approach which was, without explanation, not followed in subsequent decision-making. The only solid foundation for the forming doctrine in relation to the Charter is stating that the Charter must be considered as a treaty under article 7 section 5 of the Constitution.
\end{abstract}

Keywords: Charter of Fundamental Rights of the EU; Constitutional Court; self-limiting approach

Kl’účové slová: Charta základných práv EÚ; Ústavný súd; samo obmedzujúci prístup

DOI: $10.14712 / 23366478.2018 .35$

\section{1. ÚVOD}

Je osem rokov vel'a alebo málo na vytvorenie doktríny v zmysle vyhranených názorov, zásad a pravidiel vo vzt’ahu $\mathrm{k}$ aplikácii Charty základných práv EÚ (d’alej len „Charta“)? Tol'ko rokov totiž už uplynulo od doby, ked' sa Charta stala v dôsledku zmien zavedených Lisabonskou zmluvou súčast'ou primárneho práva Európskej únie (d’alej len „Únia“). Síce len prostredníctvom odkazu v článku 6 Zmluvy o Európskej únii (d’alej len „ZEÚ“), ale napriek tejto skutočnosti je Charta od roku 2009 všeobecne akceptovaná ako záväzný katalóg základných práv, ktorým Únia a členské štáty pri vykonávaní práva Únie poskytujú ochranu. ${ }^{1}$

Ked' pri hl'adaní odpovede na otázku z úvodu vychádzame z judikatúry Ústavného súdu Slovenskej republiky (d’alej len „Ústavný súd“), tak zist’ujeme, že v tomto prípade

1 Pozri napríklad WALKILA, S.: Horizontal Effect of Fundamental Rights in EU Law. Groningen: Europa Law Publishing, 2016, s. 96 a nasledujúce alebo CABRILLAC, R.: Liberté et droits fondamentaux. Paris: DALLOZ, 2013, s. 86. 
osem rokov nestačilo. A nič na tom nemení ani skutočnost', že určite existujú zásadné rozhodnutia Ústavného súdu, v ktorých sa snažil vymedzit' svoj vzt’ah k Charte, k otázke jej aplikovatel’nosti, k otázke jej vplyvu na vnútroštátny právny poriadok a k jej vnímaniu z pohl'adu vnútroštátneho práva. Pri vzájomnom pospájaní týchto rozhodnutí však nezískame ucelený obraz. Vidíme len obraz, v ktorom sa niektoré časti prekrývajú, niektoré spolu neladia, niektoré sú umiestnené nesprávne a niektoré ešte chýbajú. Je to obraz, ktorý sa ešte len tvorí. Tento stav, stav dotvárania doktríny, by bol v tomto časovom období celkom v poriadku, keby mal obraz, teda doktrína Ústavného súdu vo vzt’ahu k Charte, už pevné základy, kontúry. Na túto etapu tvorby doktríny by malo byt' osem rokov dostatočným časovým obdobím.

V tomto príspevku sa pokúsime zistit', či je za aktuálneho stavu možné konštatovat', že Ústavný súd už má pevne vytvorené základy svojej doktríny vo vzt’ahu k Charte, pričom budeme vychádzat' $z$ konkrétnych rozhodnutí Ústavného súdu vydaných v rámci konania o súlade právnych predpisov.

\section{PL. ÚS 10/2014 AKO ZÁKLAD DOKTRÍNY?}

V konaní vedenom pod sp. zn. PL. ÚS 10/2014 skupina poslancov ako navrhovatel' požadovala vyslovenie nesúladu napadnutých ustanovení zákona č. 351/2011 Z. z. o elektronických komunikáciách $\mathrm{v}$ znení neskorších predpisov, § 116 zákona č. 301/2005 Z. z. Trestný poriadok v znení neskorších predpisov a § 76a ods. 3 zákona č. 171/1993 Z. z. o Policajnom zbore v znení neskorších predpisov s čl. 13 ods. 4, čl. 16 ods. 1, čl. 19 ods. 2 a 3, čl. 22 a čl. 26 Ústavy Slovenskej republiky (d’alej len „Ústava“), čl. ods. 1, čl. 10 ods. 2 a 3, čl. 13 a čl. 17 Listiny základných práv a slobôd, čl. 8 a čl. 10 Dohovoru o ochrane l’udských práv a základných slobôd (d’alej len „Dohovor“) a čl. 7, čl. 8, čl. 11 a čl. 52 ods. 1 Charty. Ústavný súd nálezom z 29. apríla 2015 (d’alej len „nález 10/2014“) vyslovil nesúlad týchto zákonov (ich jednotlivých ustanovení) s Ústavou a Dohovorom a nevyhovel návrhu v časti, v ktorej navrhovatel' namietal nesúlad s Chartou. ${ }^{2}$

Pre základ tvoriacej sa doktríny Ústavného súdu vo vzt’ahu k Charte sú v tomto náleze dôležité dva závery.

\subsection{CHARTA AKO MEDZINÁRODNÁ ZMLUVA PODLA ČLÁNKU 7 ODS. 5 ÚSTAVY}

Prvým je výslovné konštatovanie, že Chartu považuje Ústavný súd z pohladu Ústavy za medzinárodnú zmluvu o l'udských právach a základných slobodách a preto má v zmysle článku 7 ods. 5 Ústavy prednost' pred zákonmi. Vzhl’adom na netypický proces tvorby Charty, ktorá neprešla klasickými štádiami tvorby medziná-

2 V súvislosti s týmto konaním je potrebné pripomenút', že napadnuté ustanovenia zákonov predstavovali transpozičný nástroj vo vzt’ahu k smernici 2006/24/ES z 15. marca 2006 o uchovávaní údajov vytvorených alebo spracovaných $\mathrm{v}$ súvislosti s poskytovaním verejne dostupných elektronických komunikačných služieb alebo verejných komunikačných sietí a o zmene a doplnení smernice 2002/58/ES, ktorá bola počas konania pred Ústavným súdom vyhlásená Súdnym dvorom za neplatnú (C-293/12 Digital Rights Ireland a Seitlinger a i., ECLI:EU:C:2014:238). 
rodnej zmluvy, ${ }^{3}$ je toto konštatovanie osobitne významné. Znamená to, že Charta spíňa požiadavky vyplývajúce z článku 7 ods. 5 Ústavy ${ }^{4} \mathrm{v}$ spojení s článkom 7 ods. 4 Ústa$\mathrm{vy}^{5}$, teda že sa považuje za medzinárodnú zmluvu, ktorá bola ratifikovaná Slovenskou republikou, pred ratifikáciou s ňou vyslovila súhlas Národná rada Slovenskej republiky a bola vyhlásená spôsobom ustanoveným zákonom. Ďalším dôsledkom takéhoto vnímania Charty je skutočnost', že Charta môže byt' referenčným kritériom v konaní o súlade právnych predpisov podla článku 125 ods. 1 písm. a) Ústavy 6 a teda do právomoci Ústavného súdu patrí aj skúmanie súladu vnútroštátnej právnej úpravy, pri ktorej je splnená podmienka vykonávania práva Únie, s Chartou.

Tým sa však zvýrazňuje problém spojený s článkom 144 Ústavy, v zmysle ktorého sú sudcovia viazaní takou medzinárodnou zmluvou, akou je podla Ústavného súdu Charta, a ak sa domnievajú, že iný všeobecne záväzný predpis je s ňou v rozpore, tak majú konanie prerušit' a podat' návrh na začatie konania o súlade právnych predpisov. A tu sa dostávame do priameho rozporu s princípom prednosti práva Únie, ktorý Slovenská republika akceptovala pristúpením k Únii v podobe judikovanej Súdnym dvorom. Už v roku 1978 Súdny dvor v rozsudku vo veci C-106/77 Simmenthal ${ }^{7}$ uviedol, že vnútroštátny sudca aplikujúci v rámci svojej právomoci ustanovenia komunitárneho práva má povinnost' zabezpečit' plnú účinnost' týchto ustanovení tým, že na základe vlastného rozhodnutia ponechá neaplikované všetky ustanovenia vnútroštátneho práva, ktoré sú v rozpore s komunitárnym právom a to bez toho, aby žiadal alebo čakal na ich zrušenie legislatívnou cestou alebo akýmikol'vek ústavnými procedúrami. Posúdenie rozporu medzi vnútroštátnou úpravou a Chartou má byt' teda v rukách sudcu všeobecného súdu a v záujme plnej efektivity práva Únie nemá toto rozhodnutie prenechávat' na iný subjekt, napríklad na Ústavný súd.

Kým dlhú dobu bol problém článku 144 ods. 2 Ústavy len v teoretickej rovine, v súčasnosti už máme praktickú ukážku toho, ako sa Ústavný súd k tomuto problému postavil. Vo veci PL. ÚS 8/2016 prijal Ústavný súd na d’alšie konanie ${ }^{8}$ návrh Najvyššieho súdu Slovenskej republiky (d’alej len „Najvyšší súd“) na začatie konania o súlade právnych predpisov o súlade $\S 120$ ods. 2 zákona č. 404/2011 Z. z. o pobyte cudzincov a o zmene a doplnení niektorých d'alších zákonov s Ústavou, Dohovorom a Chartou. Odobril tak

3 K procesu vzniku Charty a jej zaradenia na úroveň primárneho práva pozri napríklad JACQUE, J. P.: Droit institutionnel de l'Union européenne. Paris: DALLOZ, 2015, s. 68 alebo CLERGERIE, J.-L. - GRUBER, A. - RAMBAUD, P.: L'Union européenne. Paris: DALLOZ, 2016, s. 103.

4 Článok 7 ods. 5 Ústavy znie: „Medzinárodné zmluvy o l’udských právach a základných slobodách, medzinárodné zmluvy, na ktorých vykonanie nie je potrebný zákon, a medzinárodné zmluvy, ktoré priamo zakladajú práva alebo povinnosti fyzických osôb alebo právnických osôb a ktoré boli ratifikované a vyhlásené spôsobom ustanoveným zákonom, majú prednost' pred zákonmi.“

5 Článok 7 ods. 4 Ústavy znie: „Na platnost’ medzinárodných zmlúv o ludských právach a základných slobodách, medzinárodných politických zmlúv, medzinárodných zmlúv vojenskej povahy, medzinárodných zmlúv, z ktorých vzniká Slovenskej republike členstvo v medzinárodných organizáciách, medzinárodných hospodárskych zmlúv všeobecnej povahy, medzinárodných zmlúv, na ktorých vykonanie je potrebný zákon, a medzinárodných zmlúv, ktoré priamo zakladajú práva alebo povinnosti fyzických osôb alebo právnických osôb, sa vyžaduje pred ratifikáciou súhlas Národnej rady Slovenskej republiky.“

6 Článok 125 ods. 1 písm. a) Ústavy znie: „Ústavný súd rozhoduje o súlade zákonov s ústavou, s ústavnými zákonmi a s medzinárodnými zmluvami, s ktorými vyslovila súhlas Národná rada Slovenskej republiky a ktoré boli ratifikované a vyhlásené spôsobom ustanoveným zákonom.“

7 C-106/77 Amministrazione delle finanze dello Stato/Simmenthal, ECLI:EU:C:1978:49.

8 Uznesenie Ústavného súdu z 29. júna 2016 vo veci PL. ÚS 8/2016. 
konanie Najvyššieho súdu, ktoré má síce oporu v Ústave, ale súčasne je porušením princípu prednosti práva Únie, pretože v zmysle záverov plynúcich z rozsudku Simmenthal mal rozpor vnútroštátnej normy s právom Únie (v tomto prípade s Chartou) posúdit' sám vnútroštátny súd (prípadne za pomoci prejudiciálnej otázky výkladu práva Únie adresovanej Súdnemu dvoru) a nečakat' na konštatovanie tohto rozporu Ústavným súdom. Domnievame sa, že Ústavný súd mal odmietnut' návrh Najvyššieho súdu v časti týkajúcej sa rozporu vnútroštátnej úpravy s Chartou pre nedostatok právomoci. Oprávnenie (aj povinnost') posúdit' tento rozpor patrilo totiž, na základe uplatnenia princípu prednosti práva Únie pred článkom 144 ods. 2 Ústavy, Najvyššiemu súdu. Zdá sa však, že Ústavný súd a ani Najvyšší súd si tento problém vôbec neuvedomujú, ked’že ani návrh na začatie konania o súlade právnych predpisov a ani uznesenie z predbežného prerokovania návrhu neobsahujú žiadne pochybnosti o súlade článku 144 ods. 2 Ústavy s právom Únie.

Z toho by sa dalo vyvodzovat', že oba najvyššie súdy nehodlajú aplikovat' princíp prednosti práva Únie vo vztahu k Ústave. Takýto prístup by si však vyžadoval, napriek jeho vecnej nesprávnosti, náležité doktrinálne odôvodnenie alebo aspoň sformovanie výhrady proti prednosti Charty pred Ústavou. Domnievame sa, že najvhodnejším spôsobom riešenia tejto otázky by bola novelizácia článku 144 Ústavy jeho zosúladením s princípom aplikačnej prednosti práva Únie.

\subsection{SAMO OBMEDZUJÚCI PRÍSTUP PRI UPLATŇOVANÍ PRÁVOMOCI ÚSTAVNÉHO SÚDU}

Druhým záverom dôležitým pre tvoriacu sa doktrínu Ústavného súdu vo vzt’ahu k Charte, ktorý vyplýva z nálezu 10/2014, je použitie tzv. samo obmedzujúceho prístupu $\mathrm{k}$ výkonu právomoci Ústavného súdu, ktorý spočíva $\mathrm{v}$ tom, že po konštatovaní nesúladu napadnutého zákona s Ústavou alebo ústavnými zákonmi už nie je v zásade potrebné preskúmat' aj jeho nesúlad s právom Únie a teda aj s Chartou. Tento prístup Ústavný súd odôvodnil tým, že konštatovaním nesúladu s Ústavou alebo ústavnými zákonmi sa naplní účel sledovaný navrhovatel'mi, ked’že v zmysle článku 125 ods. 3 Ústavy dochádza $\mathrm{k}$ strate účinnosti napadnutej právnej úpravy a po márnom uplynutí šiestich mesiacov aj k prípadnej strate jej platnosti, čím sa zároveň odstráni aj možný nesúlad napadnutej právnej úpravy s Chartou. Podl'a Ústavného súdu, po vyslovení nesúladu s Ústavou alebo ústavnými zákonmi zaniká predmet konania o súlade právnych predpisov vo vzt’ahu k namietanému nesúladu s právom Únie.

Nechceme sa v tomto príspevku venovat' detailnej analýze a kritike nálezu 10/2014, to sme už urobili v iných článkoch. ${ }^{9}$ Pre potreby tohto príspevku len pripomenieme naše pochybnosti týkajúce sa tohto samo obmedzujúceho prístupu Ústavného súdu a nebezpečenstvá, ktoré s ním súvisia.

9 MAZÁK, J. - JÁNOŠÍKOVÁ, M.: Charta základných práv EÚ v konaní o súlade právnych predpisov: Zatial' rutina namiesto doktríny. Právny obzor: teoretický časopis pre otázky štátu a práva, 2015, č. 6, s. 590-601 alebo MAZÁK, J. - JÁNOŠ́́KOVÁ, M.: Prienik Charty základných práv Európskej únie do vnútroštátneho práva na príklade Slovenskej republiky. Acta Universitatis Carolinae Iuridica, 2016, č. 2 , s. 9-16. 
Ústavný súd v náleze 10/2014 nevysvetlil, prečo nepoužíva rovnaký prístup aj k Dohovoru. Pritom v prípade Dohovoru sa nejedná o zmluvu, ktorej by prednostné postavenie $\mathrm{v}$ slovenskom právnom poriadku zabezpečoval článok 7 ods. 5 Ústavy. ${ }^{10}$

Samo obmedzujúci prístup Ústavného súdu nereflektuje závery plynúce z rozsudku Súdneho dvora vo veci Melloni ${ }^{11}$ Tento prípad, v ktorom prejudiciálne otázky prvýkrát predložil španielsky ústavný súd, totiž poukazuje na to, že môže nastat' situácia, že vnútroštátny právny akt bude síce $\mathrm{v}$ rozpore $\mathrm{s}$ ústavou členského štátu, ale bude $\mathrm{v}$ súlade s Chartou, čo by znamenalo, že nie je možné rozhodnút' o neaplikácii vnútroštátneho práva pre rozpor s ústavou, pretože by to narušilo princíp prednosti, jednotnosti a účinnosti práva Únie. ${ }^{12}$ Pri použití samo obmedzujúceho prístupu sa však Ústavný súd po konštatovaní nesúladu napadnutého právneho predpisu s Ústavou už nedostane ku skúmaniu jeho súladu/nesúladu s Chartou.

\section{PL. ÚS 2/2016 AKO POTVRDENIE DOKTRÍNY?}

\subsection{PRÍLEŽITOSŤ NA POTVRDENIE SAMO OBMEDZUJÚCEHO PRÍSTUPU ÚSTAVNÉHO SÚDU}

Ďalším konaním, v ktorom mohol Ústavný súd potvrdit' svoj prístup k Charte načrtnutý v náleze 10/2014, bolo konanie vedené pod sp. zn. PL. ÚS 2/2016. Verejná ochrankyňa práv a generálny prokurátor Slovenskej republiky ako navrhovatelia požadovali vyslovenie nesúladu napadnutých ustanovení zákona č. 180/2014 Z. z. o podmienkach výkonu volebného práva a o zmene a doplnení niektorých d’alších zákonov v znení neskorších predpisov (konkrétne išlo o prekážku práva volit' spočívajúcu vo výkone trestu odňatia slobody uloženého za obzvlášt' závažný zločin a prekážku práva volit' spočívajúcu v pozbavení spôsobilosti na právne úkony) s dotknutými ustanoveniami Ústavy, Dodatkového protokolu k Dohovoru, Medzinárodného paktu o občianskych a politických právach, Dohovoru o právach osôb so zdravotným postihnutím a s Chartou. ${ }^{13}$

Ústavný súd sa rozhodol skúmat' namietaný nesúlad osobitne vo vzt'ahu k vol'bám do Národnej rady Slovenskej republiky, k vol'bám do Európskeho parlamentu a k vol'bám prezidenta Slovenskej republiky. Nálezom z 22. marca 2016 (d’alej len „nález 2/2016“) Ústavný súd vo vzt’ahu k vol’bám do Európskeho parlamentu vyslovil nesúlad napadnutých ustanovení zákona č. 180/2014 Z. z s Ústavou, Dodatkovým protokolom k Dohovoru, Medzinárodným paktom o občianskych a politických právach a nakoniec

10 Dohovor je síce jednoznačne zmluvou o l’udských právach a základných slobodách v zmysle článku 7 ods. 5 Ústavy, avšak toto ustanovenie sa vzt’ahuje len na medzinárodné zmluvy, ktorými je Slovenská republika viazaná od nadobudnutia účinnosti tzv. euronovely Ústavy (ústavný zákon č. 90/2001 Z. z. účinný od 1. januára 2002).

11 C-399/11 Melloni, ECLI:EU:C:2013:107.

12 Bližšie k tomu pozri MAZÁK, J. - JÁNOŠÍKOVÁ, M.: Charta základných práv EÚ v konaní o súlade právnych predpisov: Zatial' rutina namiesto doktríny. Právny obzor: teoretický časopis pre otázky štátu a práva, 2015, č. 6, s. 590-601.

13 Pre úplnost' treba dodat', že na rozpor s Chartou poukazoval v svojom podaní len generálny prokurátor. 
aj s Chartou, konkrétne s jej článkom 39 ods. 2, podl'a ktorého sú poslanci do Európskeho parlamentu volení vo všeobecných, priamych a slobodných vol'bách tajným hlasovaním.

\subsection{ROZPOR S CHARTOU AKO NEOBJASNENÁ REZIGNÁCIA NA SAMO OBMEDZUJÚCI PRÍSTUP}

Už pri čítaní výroku nálezu 2/2016 vznikajú pochybnosti, či Ústavný súd použil vo vzt’ahu k Charte samo obmedzujúci prístup, ktorý sám len pred necelým rokom zaviedol. Ak by ho bol totiž použil v podobe, ktorú popísal v náleze 10/2014, tak po konštatovaní nesúladu zákona č. 180/2014 Z. z. s článkom 30 ods. 3 Ústavy, podla ktorého je volebné právo všeobecné, rovné a priame a vykonáva sa tajným hlasovaním, sa mal naplnit' účel sledovaný navrhovatel'mi, ked’že v zmysle článku 125 ods. 3 Ústavy dochádza k strate účinnosti napadnutej právnej úpravy a po márnom uplynutí šiestich mesiacov aj k prípadnej strate jej platnosti, čím sa zároveň mal odstránit' aj možný nesúlad napadnutej právnej úpravy s článkom 39 ods. 2 Charty. Po vyslovení nesúladu s Ústavou malo teda dôjst' $\mathrm{k}$ zániku predmetu konania o súlade právnych predpisov vo vzt'ahu k namietanému nesúladu s Chartou a v tejto časti mal Ústavný súd návrhu nevyhoviet'.

Ked’že však Ústavný súd konštatoval nesúlad napadnutých ustanovení zákona č. 180/2014 Z. z. aj s Chartou, pravdepodobne došlo k spresneniu podmienok pre použitie samo obmedzujúceho prístupu. Pod'me sa teda pozriet', ako Ústavný súd vysvetlil, že po konštatovaní nesúladu s Ústavou sa ešte zaoberal aj súladom/nesúladom napadnutej právnej úpravy s Chartou.

Vychádzajúc z bodu 54, ktorý je zaradený v náleze $2 / 2016 \mathrm{v}$ jeho V. časti s nadpisom „Východiská a právne závery“, by sa mohlo zdat', že Ústavný súd bude Chartu použivat' len ako pomôcku pri výklade Ústavy. Ústavný súd v tomto bode pripomína, že Charte je priznané postavenie medzinárodnej zmluvy podl’a článku 7 ods. 5 Ústavy a teda ovplyvní výklad Ústavy, ked’že Ústavný súd štandardne vykladá Ústavu s prihliadnutím na medzinárodné právo. Okrem toho, povinnost' zohl'adnit' Chartu pri výklade vnútroštátneho práva vyplýva aj z povinnosti lojálnej spolupráce zakotvenej v článku 4 ods. 4 ZEÚ. V zmysle teórie práva Európskej únie sa tak Ústavný súd vlastne prihlásil k nepriamemu účinku Charty. Ak by však Ústavný súd zostal len pri tomto použití Charty, konštatoval by len nesúlad s Ústavou vykladanou vo svetle Charty. Zjavne to však neurobil a zaoberal sa aj nesúladom vnútroštátnej úpravy priamo s Chartou.

Vo výsledku konštatovaný nesúlad napadnutých ustanovení zákona č. 180/2014 Z. z. vychádzal z nasledovnej konštrukcie. Všetky pramene, ktoré boli zvolené ako referenčné v tomto konaní, predpokladajú, že právo volit' a byt' volený nie je absolútnym právom a teda môže byt' obmedzené, pričom však obmedzenie musí spĺńat' určité podmienky - musí byt' stanovené zákonom, musí rešpektovat' podstatu práva volit', musí sledovat' legitímny ciel' spočívajúci v dôležitom verejnom záujme a podl’a zásady proporcionality musí byt' vhodné a nevyhnutné na dosiahnutie sledovaného ciela.

Ústavný súd mal za nesporné, že obmedzenie volebného práva z dôvodu výkonu trestu odňatia slobody uloženého za spáchanie obzvlášt' závažného zločinu je ustanovené zákonom a rešpektuje podstatu volebného práva. 
Problematické sa však ukázalo splnenie podmienky, že obmedzenie volebného práva musí sledovat' legitímny ciel' dôležitého verejného záujmu. Ústavný súd dospel k záveru, že neexistuje žiadny relevantný verejný záujem smerujúci k tomu, aby bol osobám vo výkone trestu odñatia slobody odopretý výkon aktivneho volebného práva vo volbách do národnej rady a Európskeho parlamentu. V tejto časti je možné v argumentácii Ústavného súdu vidiet' inšpiráciu judikatúrou Súdneho dvora týkajúcou sa povinnosti inštitúcií Únie odôvodnit’ právny akt, hlavne rozsudkom vo veci C-409/13. ${ }^{14}$ Domnievame sa však, že si Ústavný súd plne neuvedomil, že argumentácia Súdneho dvora $\mathrm{v}$ uvedenom rozhodnutí bola zasadená do iného právneho rámca a to hlavne vzhl'adom na výslovne stanovenú povinnost' uviest' $\mathrm{v}$ právnych aktoch Únie odôvodnenia a odkazy na všetky návrhy, iniciatívy, odporúčania, žiadosti alebo stanoviská ustanovené v zmluvách vyplývajúcu z článku 296 ZFEÚ. Preto nepovažujeme za správny názor Ústavného súdu vyjadrený v bode 83 nálezu 2/2016, že z dôvodu absencie existencie a deklarovania legitímneho ciel'a spočivajúceho $v$ dôležitom právnom záujme možno konštatovat nesúlad napadnutej právnej úpravy s referenčnými normami. Je potrebné totiž rozlišovat' medzi absenciou existencie legitímneho ciel'a a absenciou deklarovania legitímneho ciel'a, pričom absencia deklarovania legitímneho ciel'a vo vnútroštátnej norme nemôže mat', na rozdiel od práva Únie, vplyv na jej súlad s referenčnými normami, ktoré vo vzt'ahu $\mathrm{k}$ vnútroštátnemu právu nestanovujú podobnú povinnost', ako vyplýva z článku 296 ZFEÚ vo vzt’ahu k normám sekundárneho práva Únie.

\subsection{STAČÍ NA APLIKÁCIU CHARTY A ZÁNIK SAMO OBMEDZUJÚCEHO PRÍSTUPU MLČANIE ÚSTAVNÉHO SÚDU?}

Konštatovanie o neexistencii žiadneho relevantného verejného záujmu na obmedzení volebného práva osôb vo výkone trestu odňatia slobody vo vol'bách do národnej rady a Európskeho parlamentu bolo teda hlavným dôvodom pre záver o nesúlade $\S 4$ písm. b) zákona č. 180/2014 Z. z. s Ústavou, Dodatkovým protokolom k Dohovoru, Medzinárodným paktom o občianskych a politických právach a s Chartou. Jediné vysvetlenie, prečo na rozdiel od nálezu 10/2014 tentokrát Ústavný súd po konštatovaní rozporu s Ústavou konštatoval aj rozpor s Chartou, je obsiahnuté v závere bodu 93 nálezu 2/2016 - ked’že sa na vo vol'by do Európskeho parlamentu uplatňuje aj článok 39 ods. 2 Charty, ..., ustanovenie § 4 písm. b) nie je v súlade ani s článkom 39 ods. 2 Charty.

Tomuto záveru nepredchádza žiadna zmienka o existencii samo obmedzujúceho prístupu vo vzt'ahu $\mathrm{k}$ Charte a už vôbec nie o tom, prečo sa tento prístup v tomto prípade nepoužije. Žiadne vysvetlenie, prečo po konštatovaní rozporu s Ústavou nezaniká predmet konania o súlade právnych predpisov vo vzt’ahu $\mathrm{k}$ namietanému nesúladu s Chartou tak, ako to popísal v náleze 10/2014. Ked' už Ústavný súd zvolil iný prístup ako v náleze 10/2014, domnievame sa, že vo vzt'ahu k Charte by bolo presnejšie konštatovat' nesúlad napadnutej právnej úpravy nielen s článkom 39 ods. 2 Charty, ale spojit’ toto

14 C-409/13 Rada/Komisia, ECLI:EU:C:2015:217. 
ustanovenia s článkom 52 ods. 1 Charty, ktorý upravuje podmienky obmedzenia práv upravených $\mathrm{v}$ Charte, ked’že napadnutá úprava nerešpektovala práve tieto podmienky.

Čo sa týka prekážky práva volit’ spočívajúcej v pozbavení spôsobilosti na právne úkony, Ústavný súd postupoval rovnako ako pri obmedzení volebného práva z dôvodu výkonu trestu odňatia slobody uloženého za spáchanie obzvlášt' závažného zločinu a teda skúmal, či toto obmedzenie spíña kritéria stanovené na to, aby mohlo íst' o dovolené obmedzenie.

Splnenie prvej podmienky, požadujúcej, aby obmedzenie bolo ustanovené zákonom, považoval za nesporné. Zaujímavé je, že sa nevyjadril k druhej podmienke, v zmysle ktorej obmedzenie musí rešpektovat' podstatu práva volit'. Pri hl'adaní ciel'a sledovaného obmedzenie práva volit', čo je tretia podmienka, ktorú musí obmedzenie spíňat', už Ústavný súd neskúmal, či je tento ciel' deklarovaný. Vychádzajúc z námietky vlády (bod 118 nálezu) uznal za legitímny ciel' obmedzenia zaistenie toho, aby elektorát pozostával $z$ osôb, ktoré sú schopné vedome a racionálne sa rozhodovat' a porozumiet' významu, účelu a účinkom volieb. Za nesplnenú považoval štvrtú podmienku týkajúcu sa proporcionality medzi legitímnym ciel'om a obmedzením práva volit', konkrétne konštatoval, že obmedzenie nie je nevyhnutné pre dosiahnutie ciel'a sledovaného obmedzením, pretože by muselo platit', že žiadna osoba pozbavená spôsobilosti na právne úkony nie je schopná porozumiet' významu, účelu a účinkom volieb, pričom však takéto tvrdenie nie je možné prijat'. Domnievame sa, že tak ako to popísal Ústavný súd, ide skôr o nevhodnost' ako o nevyhnutnost' obmedzenia vo vzt'ahu k ciel'u. Pri nevyhnutnosti totiž skúmame, či neexistujú iné vhodné opatrenia, ktoré by predstavovali menší zásah do obmedzovaného práva.

Aj v prípade prekážky práva volit' spočívajúcej v pozbavení spôsobilosti na právne úkony Ústavný súd po konštatovaní nesúladu právnej úpravy s Ústavou, Dodatkovým protokolom k Dohovoru, Medzinárodným paktom o občianskych a politických právach a Dohovorom o právach osôb so zdravotným postihnutím vyhlásil aj nesúlad s Chartou. A to znovu bez akéhokol'vek vysvetlenia, prečo nevyužil samo obmedzujúci prístup, ktorý vo vzt'ahu $\mathrm{k}$ Charte použil pred niekol'kými mesiacmi. Aj v tomto prípade sa domnievame, že by bolo logickejšie pri konštatovaní nesúladu spojit' článok 39 ods. 2 Charty s článkom 52 ods. 1 Charty, ktorý upravuje podmienky obmedzenia práv upravených v Charte, ked’že napadnutá úprava nerešpektoval práve tieto podmienky.

\section{NAMIESTO ZÁVERU: ARBITRÁRNE POUŽÍVANIE SAMO OBMEDZUJÚCEHO PRÍSTUPU JE NA HRANE LEGITIMITY}

Kritika konečných rozhodnutí Ústavného súdu, v ktorých sa v rovnakých situáciách diametrálne inak, so zretel’om na samo obmedzujúci prístup k uplatneniu svojej právomoci, riešila otázka aplikácie Charty, vyvoláva vážny problém legitimity postupov a rozhodovania Ústavného súdu. Považujeme preto za nevyhnutné upozornit', namiesto záveru, na základný formát, ktorý je potrebné v rozhodovaní takých súdov, akým je Ústavný súd, dodržat', aby nedošlo k ohrozeniu princípov právneho štátu a k porušeniu medzinárodných záväzkov Slovenskej republiky (čl. 1 ods. 2 Ústavy). 
Legitimita súdov a osobitne najvyšších a ústavných súdov sa spravidla delí na tri druhy ${ }^{15}$ :

a) inštitucionálna legitimita, ktorá znamená, že verejnost' vníma vo všeobecnosti súd ako dôveryhodnú inštitúciu, ktorej rozhodnutia zasluhujú rešpekt;

b) materiálna legitimita, ktorej obsahom je zásadný súhlas verejnosti s podstatou rozhodnutia súdu a

c) autoritatívna legitimita, ktorej základnou črtou je to, že verejnost' je presvedčená, že konkrétne rozhodnutie súdu má byt' vykonané alebo sa s ním musí súhlasit'.

Ústavný súd získava inštitucionálnu legitimitu z viacerých zdrojov. Základným zdrojom jeho legitimity je jeho postavenie v ústavnom poriadku Slovenskej republiky, pre ktoré však musí byt' typické to, že ústavný súd koná nezávisle, nestranne a s vysokou profesionalitou svojich členov. ${ }^{16}$ Jeho rozhodovanie musí súčasne striktne rešpektovat' procesné aj hmotnoprávne normy upravujúce postupy, spôsoby rozhodovania a práva účastníkov konania.

Materiálna a autoritatívna legitimita sa vzt’ahujú na konkrétne rozhodnutia. Predpokladom ich existencie je to, že ústavný súd netrpí nedostatkom inštitucionálnej legitimity. V praxi sa stretávame aj s tým, že napriek tomu, že súd ako taký má inštitucionálnu legitimitu, tak niektoré jeho rozhodnutia trpia nedostatkom materiálnej alebo aj autoritatívnej legitimity.

Jedným z najčastejších problémov legitimity ústavného súdu a jeho rozhodnutí sú také rozhodnutia, v ktorých ústavný súd nerešpektuje svoju vlastnú judikatúru, prípadne odklon od nej náležite a zrozumitel'ne nevysvetlí. Také rozhodnutia ústavného súdu sú potom častokrát spochybňované.

A to je práve aj problém dvoch nálezov Ústavného súdu, o ktorých sme v tomto príspevku písali. Niežeby nám bolo l'úto toho, že Ústavný súd upustil od samo obmedzujúceho prístupu vo vzt’ahu k Charte v rámci konania o súlade právnych predpisov. Sami sme tento prístup už niekol'kokrát kritizovali a poukazovali na problémy, ktoré prináša. Skôr sme chceli poukázat' na premárnenú príležitost' vytvorit' pevné základy doktríny Ústavného súdu vo vzt’ahu k Charte. Z nálezu 2/2016 nie je zrejmé, či ide o trvalý odklon od samo obmedzujúceho prístupu, alebo či je to z tohto pohl'adu len ad hoc rozhodnutie nezakladajúce predpoklady pre budúce rozhodnutia Ústavného súdu.

Jediným pevným bodom ešte stále sa len tvoriacej doktríny Ústavného súdu vo vzt'ahu k Charte sa tak stalo konštatovanie o tom, že Chartu je potrebné pokladat' za zmluvu podl'a článku 7 ods. 5 Ústavy. Na d'alšie dieliky celku budeme musiet' ešte počkat'.

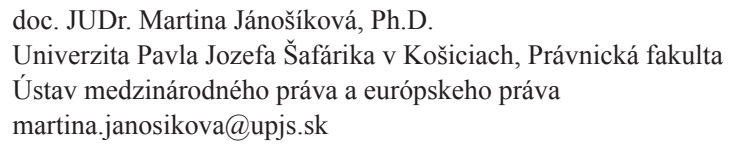

15 Bližšie k tomu pozri FALLON, R.: Legitimacy and the Constitution. Harvard Law Review, 2005, č. 6, s. $1789,1795$.

16 EVERLING, U.: On the Judge-Made Law of the European Community's Courts. In KEEFFE, D. O. (ed): Judicial Review in European Union Law. Liber Amicorum in Honour of Lord Slynn of Hadley. The Hague: Kluwer Law International, 2000, s. 36. 